Article

\title{
How Civil Servants Frame Participation: Balancing Municipal Responsibility with Citizen Initiative in Ede's Food Policy
}

\author{
Joëlla van de Griend ${ }^{*}$, Jessica Duncan and Johannes S. C. Wiskerke \\ Rural Sociology Group, Wageningen University, 6700 EW Wageningen, The Netherlands, \\ E-Mails: joella.vandegriend@outlook.com (J.v.d.G.), jessica.duncan@wur.nl (J.D.), han.wiskerke@wur.nl (J.S.C.W.) \\ * Corresponding author
}

Submitted: 14 March 2019 | Accepted: 24 July 2019 | Published: 28 October 2019

\begin{abstract}
Contemporary governance is marked by increased attention for participation of non-governmental actors (NGAs) in traditionally governmental activities, such as policy-making. This trend has been prevalent across food policy processes and reflects a key feature of food democracy. However, the role of governmental actors in facilitating and responding to this participation remains a gap in the literature. In this article, we ask how civil servants frame the participation of NGAs in policy processes. Drawing on ethnographic research, we introduce the case of civil servants working on an urban food policy for the municipality of Ede (the Netherlands). Our analysis uncovers two competing frames: 1) highlighting the responsibility of the municipality to take a leading role in food policy making, and 2) responding reflexively to NGAs. The analysis provides insights into how the framing of participation by civil servants serves to shape the conditions for participation of NGAs. It further sheds light on related practices and uncovers existing tensions and contradictions, with important implications for food democracy. We conclude by showing how, in the short term, a strong leadership role for civil servants, informed by the responsibility frame, may be effective for advancing policy objectives of the municipality. However, the reactive frame illustrates that civil servants worry this approach is not effective for maintaining meaningful participation of NGAs. This remains a key tension of participatory municipal-led urban food policy making, but balancing both municipal responsibility and an open and reactive attitude towards the participation of NGAs is useful for enhancing food democracy.
\end{abstract}

\section{Keywords}

civil servants; food democracy; non-governmental actors; participation; urban food policy

\section{Issue}

This article is part of the issue "New Perspectives on Food Democracy", edited by Basil Bornemann (University of Basel, Switzerland) and Sabine Weiland (Université Catholique de Lille, France).

(C) 2019 by the authors; licensee Cogitatio (Lisbon, Portugal). This article is licensed under a Creative Commons Attribution 4.0 International License (CC BY).

\section{Introduction}

Food democracy-understood broadly as active participation of citizens and political engagement to address conflicting values and desires related to food systemshas been said to be the "best hope for finding workable solutions to conflicts about the character and direction of the agro-food system' (Hassanein, 2003, p. 79). Unequal distribution of power in the food system propelled calls for food democracy, the essence of which lies in the redistribution of power within the food system (Booth \& Coveney, 2015). Lang (1999), who is credited with the introduction of the concept of food democracy, positions food democracy as a movement calling for better access and more equal sharing of the benefits from the food system. The concept of food democracy relates to food sovereignty, as both provide an alternative way of looking at the food system to the dominant corporate food regime perspective (Akram-Lodhi, 2015). However, food democracy puts more emphasis on con- 
sumers or citizens, while food sovereignty has traditionally focussed more on producers (Renting, Schermer, \& Rossi, 2012).

One way in which food democracy is being enacted is through the emergence of new governance mechanisms for urban food policy, such as food policy councils. Urban food policy has been defined as 'concerted action on the part of city governments to address foodrelated challenges' (Hawkes \& Halliday, 2017, p. 9). In the development of urban food policies, there is often strong emphasis on cooperation between governments and non-governmental actors (NGAs). For example, the Milan Urban Food Policy Pact (2015), now signed by 183 cities, explicitly notes that 'civil society and the private sector have major roles to play in feeding cities' and signatories to the Pact have agreed to 'engage all sectors within the food system (including neighbouring authorities, technical and academic organizations, civil society, small scale producers, and the private sector) in the formulation, implementation and assessment of all foodrelated policies, programmes and initiatives'.

While a central tenet of food democracy relates to meaningful participation (Booth \& Coveney, 2015), participation is not without contestation. Participation of NGAs in policy processes has been critiqued as symbolic ritual, for a lack of active participation, and as a symptom of an unresponsive government (Innes \& Booher, 2004). Yet, despite these challenges, this shift towards participatory governance has altered the patterns of interaction between governments and NGAs (Kooiman, 1993). As such, the spaces in which these actors are interacting, the nature of these interactions, and the related responsibilities are changing and require further investigation, particularly with respect to potential implications for the quality and success of policy-making processes (Fung, 2015). Further, while NGAs' participation is increasingly commonplace in the development and roll-out of urban food policies (Moragues-Faus \& Morgan, 2015), a gap remains in our understanding of how governmental actors understand and negotiate NGAs' participation in the traditionally governmental domain of policy making (Baldy \& Kruse, 2019). To address this gap, in this article we analyse how municipal employees, charged with developing a food policy, frame the participation of NGAs. Improved understanding of the roles and perspectives of civil servants is important given that they play a key role in enabling the participation of NGAs, for example by designing participatory processes, particularly in processes where the municipality plays a leading role (Moragues-Faus et al., 2013; Viljoen \& Wiskerke, 2012). The way in which these participatory processes are designed provides insight into a key mechanism for advancing food democracy.

Towards this end, in this article we examine how civil servants negotiate NGAs' participation in municipalityled policy making by asking the question: How do civil servants frame the participation of NGAs in urban food policy making? In what follows, we introduce theories of participation and framing which inform our analysis. This is followed by an introduction to our case study: the urban food policy of the Dutch municipality of Ede and a review of methods. We then present the results of our analysis, consisting of two frames. The first frame highlights the responsibility the municipality takes in leading a food policy, while the reactive frame calls on responsiveness to NGAs. We conclude that effective urban food policies require strong government leadership with openness and willingness to respond to NGAs and safeguard meaningful participation as a key feature of food democracy. As such, we see efforts of civil servants to balance the responsibilities of the municipality with the enhanced participation of NGAs as a useful tension.

\section{Participation in Policy Making}

As described by Hassanein (2003), participation is a key feature of food democracy. Across the literature, there are diverse understandings of what NGAs' participation involves, with the main point of contestation being the level of involvement representing actual or meaningful participation. According to Arnstein (1969, p. 216), participation refers to 'the redistribution of power that enables the have-not citizens, presently excluded from the political and economic processes, to be deliberately included in the future.' However, Castell (2016) points out that this dimension of power tends to be forgotten in much of the contemporary thinking on participation. Gaventa (2004) stresses that spaces for participation are not neutral, but shaped by power relations. He explains that 'power relations help to shape the boundaries of participatory spaces, what is possible within them, and who may enter, with which identities, discourses and interests' (Gaventa, 2004, p. 34). Recognizing that power relations are unavoidable in participatory processes, Roberts (2004, p. 320) expands on Arnstein's (1969) definition, stating participation to be 'the process by which members of a society (those not holding office or administrative positions in government) share power with public officials in making substantive decisions and in taking actions related to the community.' This article draws predominantly on this last definition, combining the sharing of power and the division in society between governmental and NGAs. This article focuses on direct participation as opposed to indirect participation (such as representation through voting). In the literature on food democracy, we can find various examples of direct participation, with food policy councils being one of the most renowned forms (see also Bassarab, Clark, Santo, \& Palmer, 2019). While participation of NGAs has been integrated into most governmental policy-making (Castell, 2016), Arnstein (1969, p. 216) has observed that participation 'is a little like eating spinach: no one is against it in principle because it is good for you.' Still, participation remains contested, not only with regards to defining the concept, but also in terms of practical implications. 


\section{Context of Participation in the Netherlands}

To understand NGAs' participation in the food policy processes of the municipality of Ede, situated in the Netherlands, an explanation of the policy context is necessary. One of the instruments being used to advise Dutch public administrators is the ladder of government participation (see Figure 1). Whereas most typologies of participation focus on explicating the role of citizens in policy-making, the ladder of the Dutch government advisory council (Raad voor het Openbaar Bestuur [ROB]; ROB, 2012) flips the perspective by defining the participation level of the government instead. The degree of government involvement ranges from 'letting go', in which the government is not involved in the process or content of a task, to 'regulating' which describes the government role of law and rule-making and the enforcement of law. The ROB argues that in each situation the role of the government can be different. However, the paradigm shift they propose involves increasingly moderate action on the part of the government. They claim that 'the vitality of society gets more room when the government limits climbing up the steps of the government participation ladder' (ROB, 2012, p. 68).

When the government takes a step back (i.e., down the ladder), it may be expecting more action from other actors. This mirrors the predominant trend in governance related to participation, with implications not only for the government, but also for citizens. However, a shift towards minimising government action does not automatically mean that there is more room for the meaningful participation of citizens. If not considered carefully, participation can be used to legitimise declining government action. From a food democracy perspective, declining government interference in the food system could, for example, make more room for corporate interests, thus contributing to the highly unequal distribution of power in the food system.

Following the literature (MacRae \& Donahue, 2013; Moragues-Faus et al., 2013; Moragues-Faus \& Morgan, 2015), and in contrast to the paradigm supporting the application of the ladder, we note the importance of both government-level leadership and citizen-led approaches. Indeed, we take as a central assumption that local food policies require strong municipal leadership and politi- cal will, especially in the context of the increasing privatization of public interests (Kamat, 2004). In turn, we are cautious of the application for the ROB ladder of government participation, recognising that it is part of Dutch strategy to move towards a 'participation society', reinforced through slogans such as 'passing the baton from government to society' (Knijn \& Hopman, 2015 , p. 647). This participation society is assessed as part of a neoliberal-driven hollowing out of government (Jessop, 2013) which is antithetical to our basic assumption. Despite this, we have opted to make use of this tool as part of our analytic framework as it reflects the broader governance context within which our case study is situated.

\section{The Case of Food Policy in Ede}

The municipality of Ede is an area in the middle of the Netherlands and includes both a rural and an urban region. The city of Ede, and the rural area surrounding it, has about 115,000 inhabitants (Gemeente Ede, 2018). The area is characterized by the presence of woods, a protected national nature park, a high number of farmers and proximity to Wageningen University, a high-profile life-sciences university with a focus on food and agriculture. With other neighbouring municipalities, agri-food companies, research institutes and higher education establishments, Ede is member of the regional partnership called the Foodvalley, which emphasizes the combination of knowledge and production of food in the area.

Ede presents a good case to better understand how policy makers frame and address NGAs' participation in municipal food policy processes because it has taken a proactive leadership approach in this regard. A second reason is that literature on local food policy often focuses on large cities like Toronto, London, San Francisco and Cape Town (Haysom, 2015; Mah \& Thang, 2013; Mansfield \& Mendes, 2012). However, smaller municipalities, which include a substantial rural area, can influence how policy makers deal with problems and solutions relating to, for example scale or budget. Finally, Ede is considered to be one of the frontrunners in the Netherlands regarding food policy (Gemeente Ede, 2017) and was awarded a Milan Pact Award for Governance in 2017 (Milan Urban Food Policy Pact, 2017).

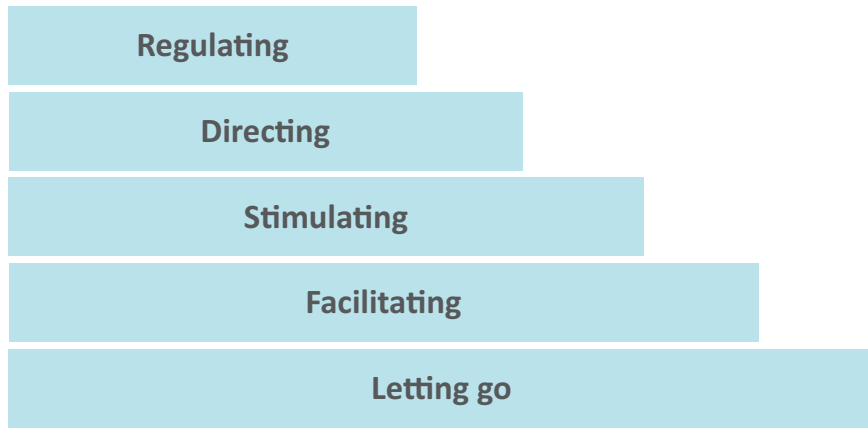

Figure 1. Ladder of government participation. Note: Figure based on ROB (2012). 


\section{Methodology: Framing}

Framing is a helpful tool to deconstruct and analyse the language that people use. Framing is the notion that issues can be 'viewed from a variety of perspectives' (Chong \& Druckman, 2007, p. 104; see also Baldy \& Kruse, 2019) and that these perspectives are constructed by actors and guide their thinking. According to Schön and Rein (1994), framing is an action in which an actor actively makes a selection to make sense of complex situations. Making this selection is an active process, meaning that the actor has agency to do so. On the other hand, there are also structures that influence the construction of frames. For civil servants, these structures include 'laws, bylaws, guidelines and other policy documents' (Castell, 2016, p. 310) that constitute frames which direct his/her action.

These structures, that are shared within and across organisations, illustrate that framing is not just an individual act. Rather, frames can be created and shared within an institution. As explained by Snow (2004, p. 405), 'collective action frames are not only cognitive structures located in the mind of individuals, but they also are properties of organizations or collectivities and can be examined as such.' This collective framing relates to the notion that a certain institution, in this case the department dealing with urban food policy within the municipality of Ede, has created frames to 'organise its operations' (Castell, 2016, p. 310). How the civil servants of the municipality of Ede frame the role of NGAs in policymaking processes impacts the roles and actions that they take. As Castell notes, 'action is always informed or even formed by frames' and the institutional framing of the local authority 'shapes the conditions of community-led initiatives' (2016, p. 310).

Within a frame, we can distinguish three functions: the diagnostic, prognostic and motivational function (Snow \& Benford, 1988). The diagnostic function points to the problem statement of the frame: what is the problem and who should be blamed. The prognostic function is a reaction on the diagnostic function and entails the solutions that are expressed within the frame. Lastly, the motivational function offers a reason for action. These three functions of frames serve as a basis for the analysis of the perceptions of civil servants of the municipality of Ede with regards to participation of NGAs in their food policy.

\subsection{Data Collection}

We apply the framing approach to enhance understanding of how civil servants in the Dutch municipality of Ede frame participation in food-related policy making. Towards this end, this article draws on data collected by way of participatory observation in the Ede municipality between September 2016 and January 2017. Ethnographic fieldwork is not commonly used to study local governance, however it can provide insight into how governance processes are experienced by those in the field (van Hulst, 2008). During the fieldwork period, the lead author attended meetings with civil servants and participated in municipal events related to food and food policy. This included regular meetings where the civil servants discussed their tasks with one another as well as meetings where one or more civil servants met with one or more NGAs to discuss a specific issue. Also observed was an open meeting in which the municipality or an NGA invited anyone interested in a certain topic related to food policy to come discuss or share information. During meetings, notes were taken. Additionally, interviews were conducted with all ten civil servants of the municipality working specifically on food issues. These interviews were recorded and transcribed with consent from the interviewees. The interviews were triangulated by three interviews with NGAs. Interviews were conducted in Dutch to avoid miscommunication, then transcribed and translated into English after analysis. The data were coded in two cycles, with the three functions of frames serving as the basis for the coding. To protect participants, we have assigned a number to each interviewee from 1 to 10 . As an additional source, we also made use of document analysis. The documents analysed include the municipal food strategy, food policy brochures and city-marketing materials from the municipality.

\section{Findings}

Despite the city having selected food as a key policy theme, governance of the food system is not one of the core tasks for the municipality and thus lacks a clear set rules and responsibilities. This means that when it comes to the engagement of NGAs in the municipal food policy, the municipality can adopt a variety of approaches ranging from no government involvement at all (low on the ladder of government participation) to the creation and enforcement of laws (high on the ladder; ROB, 2012). Importantly, civil servants play a key role in shaping how the municipality implements these processes.

The analysis of the case study begins with describing the initiation of the food policy and how NGAs where involved during the start-up phase. From our analysis, we have identified two distinct frames related to participation held by civil servants working on the theme of food. The first is as the municipality we take responsibility, or the responsibility frame. The second is initiative should come from society (Interviewee 7), or the reactive frame. As our analysis shows, the two frames relate to two roles that civil servants of the municipality see for themselves in the development of a municipal food policy, and as such they often find themselves operating between two competing frames.

\subsection{Start of Ede's Food Policy}

In 2012, the municipal councillors of Ede created a new vision for the city to guide the future direction of policy. Ede chose the theme of 'food' as a central point in their 
vision of the future. One of the aldermen from the municipality became the portfolio holder for this theme (the first in the Netherlands) and the portfolio was secured with a budget. A food vision was designed to connect several policy areas like health, economy and social work. Despite the integral character, the vision focuses more on improving the economic opportunities of the city and becoming a socially stronger and healthier city. As the municipality notes, 'it is not the question what Ede can do with food, but what food can do for Ede' (Gemeente Ede, 2015). Consequently, in the context of Ede's food policy, food is understood as an instrument that can be applied as a solution to other policy domains. The local government, knowledge institutes, and businesses are mentioned in this food vision, but above all the motivation and initiatives of the inhabitants of Ede are stated as being of vital importance for the success of the municipality's food vision of Ede (Gemeente Ede, 2015).

When the municipality of Ede decided to formulate its food vision, it noticed that there was little knowledge on food issues amongst staff of the municipality and that they needed expertise from external parties in the region. The municipality tried to select people with various backgrounds, including from 'schools, companies, knowledge institutes, hospitality industry and politicians' (Interviewee 1). Selected people were invited for various feedback moments during the starting phase of the food policy. The identification, selection and invitation of these people was carried out by the civil servants who made use of the following criteria: that the person was recognised as an expert on food-related issues and they were known to the network of the civil servants (Interviewee 1). At the start of the food policy, this network was limited but it has expanded over the years (Interviewee 1). Over time, civil servants believe they will find the right parties to participate in projects. As expressed by one interviewee, 'you just have to start, and that is also fine and sometimes you cannot involve all the right parties from the start on because you do not know them yet' (Interviewee 9). This displays the willingness of the civil servant to take a leading role in the process to get things moving. It also demonstrates an awareness that not all parties that would ideally be participating are already part of the process. However, at the same time, it also shows that a top-down approach at the start of the urban food policy process means that civil servants need to carefully consider who they invite and who gets to influence the process.

\subsection{The Responsibility Frame}

This frame relates to the way civil servants perceive the responsibility of the municipality in the governance of the food system. Responsibility in this frame manifests as the municipality taking on a leadership role in developing a food policy. Though food is not a 'traditional municipal responsibility' (MacRae \& Donahue, 2013, p. 4), by putting food on its agenda, the municipality of Ede has shown they want to address food system issues. In what follows we discuss the diagnostic, prognostic and motivational functions of the responsibility frame in relation to the data.

\subsubsection{Diagnostic Function}

The central problem described as the diagnostic function is that challenges of the current food system are not addressed sufficiently by other actors. Thus, the municipality is taking responsibility to address this gap. This was explained by Interviewee 6 , who noted that 'sometimes it can happen that as a government you see a dot on the horizon, which the partners you work with do not yet see' (Interviewee 6). Because according to the civil servant, the other actors are not yet aware of the current challenges, the municipality feels legitimized in taking a leading role on the development of the food policy.

Within the frame of responsibility, civil servants see a strong leadership role for the municipality. In this context, influencing people's personal choices is accepted when the government constructs aspects of the food system as social problems from the social-problems marketplace (Benford \& Hunt, 2003). In the case of Ede, we can also see the leadership role of the municipality reflected in the initiative that was taken to put food on the political agenda and to create a municipal food vision document. In these instances, stakeholders were invited, but the leading role was played by the municipality.

\subsubsection{Prognostic Function}

The prognostic function of the frame discusses in what ways the diagnosis of food as a public problem, and related lack of action on the part of other actors, should be treated. Our analysis suggests that civil servants see the solution to lacking action from other actors, as a strong leadership role from the municipality with a focus on agenda setting. To create a sense of urgency and to legitimise the actions of the municipality, food needs to be on the public agenda. As well, since the municipality wishes to work together with NGAs, it is important these actors have a shared problem definition. This can be achieved by the strategy of agenda-setting and communication to NGAs.

Civil servants explained that though certain issues might not be of high or widespread importance to society yet, a municipality can act to change this: 'You can indeed make sure things are GOING to come alive' (Interviewee 1). This highlights the agenda-setting power that civil servants believe they have. The civil servant sees a role for the municipality in creating the framework within which action happens, and where important topics are identified. However, there is recognition that not everything should be decided by the municipality. In this way, the municipality creates room for citizens to participate, but at the same time creates the boundaries in which this happens. 


\subsubsection{Motivational Function}

The motivational function of a frame offers a reason for action: in this case, a reason for the municipality to adopt a leading role and commit to agenda-setting. The responsibility frame as it applies to Ede is inspired by the ambition of the municipality to be a frontrunner in integrated food policy. This originates in the program goals that are formulated in the food policy vision document. In here, the ambition to focus on food-related policy is meant to position Ede as one of the European 'top regions' (Gemeente Ede, 2015, p. 3). In this sense, the motivation is to use food as a tool to enhance wealth and well-being. Furthermore, it is the ambition of Ede to use food to create a strong city profile. This combination of city-marketing and more substantive policy suggests that the municipality is using the theme of food to create a more attractive city for various groups of citizens. The consequence is restricted influence for NGAs to drive or change the course of the municipality's actions or ambitions and thus power is limited in the process. This raises questions on the ability of municipal-led urban food policy to advance food democracy.

\subsection{The Reactive Frame}

In contrast to the responsibility frame emerged the reactive frame. We understand this frame as civil servants reacting to societal processes. As noted by one respondent, 'Maybe sometimes you need to let things happen and wait until there are really initiatives coming from society and then jump into it. So let's say, not so much from above' (Interviewee 7). This statement shows an awareness of the tensions between responsibility (which can be seen as municipality leadership, or a more top-down approach) and the importance of NGAs-led or bottomup initiatives.

This realisation shows that this frame is more about empowering what already exists, than about trying to force people into a certain direction. The next sections discuss the diagnostic, prognostic and motivational functions of the reactive frame.

\subsubsection{Diagnostic Function}

The diagnostic function of the reacting frame describes the issue that is problematic according to the frame. The reactive frame problematises the one-sided communication sent from the municipality to the NGAs which is a strategy within the responsibility frame. As one civil servant summarizes: 'Right now we are sending a lot of information. However, we do not know yet how it's being received' (Interviewee 4). The civil servant explains how the municipality finds it hard to make the connection with NGAs as they do not have a clear view on how their efforts regarding food policy are being received by, for example, the residents of Ede. When asked about the role of NGAs, one civil servant (Interviewee 7) felt that right now there are some bottom-up initiatives, however they wished for more.

\subsubsection{Prognostic Function}

Within the wide frame, the solution to the diagnosis of wanting active NGAs' participation, but not yet adequately engaging them, is to look for the balance between input from the municipality and NGAs. As a consequence, when the reactive frame is invoked, we see civil servants being more cautious of expressing big ambitions, recognising that this might limit the willingness of other actors to join. In the context of this frame, the civil servants think about whether they do 'too much'; that is whether the responsibility frame dominates. One example of this was visible during an event where NGAs were invited to pitch their food-related initiatives to an audience. During the event, called Foodfloor, one of the civil servants felt that the number of contributions coming from the municipality should be limited, so she withdrew hers, because otherwise four out of eight contributions would have come from the municipality. Since the Foodfloor is considered one of the main opportunities for NGAs to participate in the food policy, the civil servants want most initiatives presented to come from the residents. There was recognition that it would be sending the wrong signal if at this event civil servants told most of the stories. We thus see the civil servants working to limit the presence of the municipality in favour of prioritizing the voices of NGAs.

\subsubsection{Motivational Function}

The motivational function of the reactive frame is twofold. Filling a more reactive role is provoked by a recognition of the importance of continuity and participation, but is also motivated by the limited resources and influence of the municipality. Civil servants are aware that they cannot force initiatives. Instead, they need to react and respond to initiatives as they arise. As one civil servant explained:

We are not going to peddle our ideas to others. For example, when we as a municipality want a tastegarden, we are not searching for a business somewhere that wants to start a taste-garden. It should be in the right order. Initiatives that come to us, we support gladly. But it has to come from them [the initiatives], so that it will sustain. Otherwise just we as a municipality do something, and when we stop, everything stops. (Interviewee 8)

This shows that as part of the reactive frame the sustainability of initiatives exceeds the preferences of the municipality for certain projects. This quote also shows, in contrast to the responsibility frame, that some of the civil servants focus on supporting initiatives instead of steering them. Further, within this frame, there is recognition that 
support from the municipality may be temporary, as current civil servants and aldermen, in their roles for a certain amount of time, cannot fully influence how their successors carry out the related food policy activities. To foster initiatives in the community that can survive changes in the public administration, it is important for the civil servants to be aware of the possible temporality of the resources the municipality invests in food governance. Also, from the literature, we can see that initiatives that receive support, but do not rely too much on the municipality, are most likely to sustain (MacRae \& Donahue, 2013).

\section{Conclusions}

In line with contemporary trends in governance, NGAs and governments are expected to interact and collaborate increasingly in the managing of complex problems (Moragues-Faus et al., 2013; Moragues-Faus \& Morgan, 2015; Viljoen \& Wiskerke, 2012). However, little has been written about the role of civil servants in these new governance arrangements. This despite the fact that in many cases civil servants actively frame and thus shape many of the conditions in which NGAs participate. In Ede, the urban food policy is centred around the municipality with other actors depending on the municipality's leadership. Simultaneously, we see consumers being stimulated to take on roles as citizens and becoming active in transforming the food system.

Our analysis has built on the work of Castell (2016), taking institutional framing as a tool for analysis. Whereas Castell (2016) mainly focused on the framing of citizen initiatives, we investigated how the civil servants frame their own role, and the implications of this for participation and food democracy. The two identified frames have different outcomes for the participation of NGAs in food democracy. For the responsibility frame, participation could be seen as limited, as it needs to be in line with municipal ambitions. Given that the diagnostic function in the responsibility frame is summarised as 'we have to take responsibility, because other actors are not addressing issues sufficiently, the sense of urgency municipal employees feel towards transforming the food system can motivate NGAs to participate. Taking on responsibility as a municipality in an area where it is not expected or prescribed by law, is taking a step higher on the ladder of government participation than formally required. Through this, we can see the municipality challenging the assumption that society is better off when the government minimizes its role, opposing the statement of the ROB (2012). When the municipality is taking on a leading role in urban food policy aimed at transforming the food system by activating those who do not yet participate or are not heard, we can say they contribute to food democracy by shifting power within the food system. This reinforces the objectives of food democracy as it was defined in this article: a more equal sharing of the benefits of the food system (Lang, 1999). At the same time, activating citizens who are not yet involved (be- yond the usual suspects) remains one of the main challenges. Food governance initiatives such as food policy councils, the Foodfloor in Ede or other gatherings might serve as vehicles to increase the attractiveness of participation for the unusual suspects, but often civil servants are the gate keepers.

Within the responsibility frame, participation of NGAs can be seen as limited because it needs to be in line with municipal ambitions. This means that participation might be more about legitimising municipal action and finding support for issues that are on the municipal agenda than about empowering NGAs and creating space for meaningful participation in food democracy. The second frame, the reactive frame, is more about letting go, thus limiting the level of government interference. A possible outcome of this frame is that the NGAs have more opportunities to participate in, and even lead, the food policy. The tension between the two frames is evident in the attitudes of the civil servants who try to balance their perceived responsibility as municipal employees with their desire to engage NGAs.

To address food democracy in urban food policy, we argue, aspects of both frames (responsibility and reactivity) are required. On the one hand, a strong leadership (top-down) role for the municipality can raise awareness about food system problems, increase knowledge amongst citizens by putting a topic on the agenda and creating spaces in which food actors can meet and generate political will for food system change. However, meaningful participation is required, which is more in line with the second 'reactive' frame. A municipal-led urban food policy can serve as a means of collective action for transformation in the food system when meaningful participation is safeguarded. Municipalities can play a leading role in spreading knowledge on food and the food system for example by funding and facilitating relevant programs. Civil servants can play a role in the sharing of ideas and facilitate spaces of interaction and re-imagining the food system by bringing together people and ideas.

To conclude, focussing on how the civil servants frame their role in food-related policy making elucidates not only how civil servants shape the conditions for NGAs and how this leads to different sorts of participation, but also how they balance competing roles in an era of participatory policy making. We wish to highlight the struggle civil servants face between long- and short-term results in the context of these two frames. In the short term, strong leadership, reflected in the responsibility frame, may be more effective. However, the reactive frame entails the realisation that only this approach is not sustainable for the future. The civil servants' perception of being held accountable for short term results may lead to a preference for working according to the responsibility frame. At the same time, the civil servants expressed the wish to reach these results in collaboration with other actors, creating space for meaningful participation and food democracy. This impasse remains one of the main challenges of participation of NGAs in urban food policy making. 
Several lessons for practice can be learnt from the case of Ede concerning NGAs' participation within the context of food democracy. Our analysis, backed by the literature, suggests that balancing between a strong leadership role for the municipality and a more reactive role may be preferable regarding the continuity of initiatives in the long term. One strategy is for municipalities to create space, both physical space as well as regulatory/experimental space, for ideas, connections and initiatives to emerge. Municipalities should find ways of ensuring these spaces are adequately representative and that relations of power are addressed to enhance and foster meaningful participation. The combination of a municipality committed to longer term urban food policy objectives and spaces where meaningful participation is safeguarded and translated into action, can support efforts to achieve inclusive and sustainable food democracy.

\section{Acknowledgments}

We are grateful to all those who participated in this research, particularly the civil servants working on food policy at the municipality of Ede. We would also like to acknowledge the helpful comments of the anonymous reviewers and the editors of this thematic issue.

\section{Conflict of Interests}

The authors declare no conflict of interests.

\section{References}

Akram-Lodhi, A. H. (2015). Accelerating towards food sovereignty. Third World Quarterly, 36(3), 563-583. https://doi.org/10.1080/01436597.2015.1002989

Arnstein, S. R. (1969). A ladder of citizen participation. Journal of the American Institute of Planners, 35(4), 216-224.

Baldy, J., \& Kruse, S. (2019). Food democracy from the top down? State-driven participation processes for local food system transformations towards sustainability. Politics and Governance, 7(4), 68-80.

Bassarab, K., Clark, J. K., Santo, R., \& Palmer, A. (2019). Finding our way to food democracy: Lessons from U.S. food policy council governance. Politics and Governance, 7(4), 32-47.

Benford, R. D., \& Hunt, S. A. (2003). Interactional dynamics in public problems marketplaces: Movements and the counterframing and reframing of public problems. In J. A. Holstein \& G. Miller (Eds.), Challenges and choices: Constructionist perspectives on social problems (pp. 153-186). New York, NY: De Gruyter.

Booth, S., \& Coveney, J. (2015). Food democracy: From consumer to food citizen. Singapore: Springer. https://doi.org/10.1007/978-981-287-423-8

Castell, P. (2016). Institutional framing of citizen initiatives: A challenge for advancing public participation in Sweden. International Planning Studies,
21(4), 305-316. https://doi.org/10.1080/13563475. 2015.1124756

Chong, D., \& Druckman, J. N. (2007). Framing theory. Annual Review of Political Science, 10, 103-126.

Fung, A. (2015). Putting the public back into governance: The challenges of citizen participation and its future. Public Administration Review, 75(4), 513-522.

Gaventa, J. (2004). Towards participatory governance: Assessing the transformative possibilities. In S. Hickey \& G. Morgan (Eds.), Participation: From tyranny to transformation? (pp. 25-41). New York, NY: Zed Books.

Gemeente Ede. (2015). Visie food! De food visie van Ede [Vision food! The food vision of Ede]. Lunteren: AMV. Retrieved from http://www.voedselbijgelderse gemeenten.nl/file.php/397/VisieFood\%21\%20Ede.pdf

Gemeente Ede. (2017). Ede; dé foodgemeente van Nederland [Ede, the municipality of food of the Netherlands]. Ede Foodstad. Retrieved from https:// www.edefoodstad.nl/nl_NL/3854/60832/ede_kiest_ voor_food.html

Gemeente Ede. (2018). Kerncijfers \& ontwikkelingen [Key figures \& developments]. Lunteren: AMV. Retrieved form https://ede.incijfers.nl//report/ Kerncijfers2018.pdf

Hassanein, N. (2003). Practicing food democracy: A pragmatic politics of transformation. Journal of $R u$ ral Studies, 19(1), 77-86. https://doi.org/10.1016/ S0743-0167(02)00041-4

Hawkes, C., \& Halliday, J. (2017). What makes urban food policy happen? Insights from five case studies. Brussels: International Panel of Experts on Sustainable Food Systems. Retrieved from http://www.ipes-food. org/images/Reports/Cities_full.pdf

Haysom, G. (2015). Food and the city: Urban scale food system governance. Urban Forum, 26, 263-281.

Innes, J. E., \& Booher, D. E. (2004). Reframing public participation: Strategies for the 21st Century. Planning Theory \& Practice, 5(4), 419-436.

Jessop, B. (2013). Hollowing out the 'nation-state' and multi-level governance. In P. Kennett (Ed.), A handbook of comparative social policy (2nd ed., pp. 11-26). Cheltenham: Edward Elgar.

Kamat, S. (2004). The privatization of public interest: Theorizing NGO discourse in a neoliberal era. Review of International Political Economy, 11(1), 155-176. https://doi.org/10.1080/0969229042000179794

Knijn, T., \& Hopman, M. (2015). Parenting support in the Dutch 'participation society'. Social Policy and Society, 14(4), 645-656. https://doi.org/10.1017/ S1474746415000329

Kooiman, J. (Ed.). (1993). Modern governance: New government-society interactions. London: Sage.

Lang, T. (1999). Food policy for the 21st century: Can it be both radical and reasonable? In M. Koc, R. MacRae, J. A. Mougeot, \& J. Welsh (Eds.), For hunger-proof cities: Sustainable urban food systems (pp. 216-224). Ottawa: International Development Research Centre.

MacRae, R., \& Donahue, K. (2013). Municipal food policy 
entrepreneurs: A preliminary analysis of how Canadian cities and regional districts are involved in food system change. Toronto: Toronto Food Policy Council and Canadian Agri-Food Policy Institute.

Mah, C. L., \& Thang, H. (2013). Cultivating food connections: The Toronto food strategy and municipal deliberation on food. International Planning Studies, 18(1), 96-110.

Mansfield, B., \& Mendes, W. (2012). Municipal food strategies and integrated approaches to urban agriculture: Exploring three cases from the global north. Urban Food Planning, 18(1), 37-60. https://doi.org/ 10.1080/13563475.2013.750942

Milan Urban Food Policy Pact. (2015). Milan urban food policy pact. Milan: Milan Urban Food Policy Pact. Retrieved from http://www.milanurbanfoodpolicypact. org/wp-content/uploads/2016/06/Milan-UrbanFood-Policy-Pact-EN.pdf

Milan Urban Food Policy Pact. (2017). Milan pact awards 2017: Winning practices. Milan: Milan Urban Food Policy Pact. Retrieved from http://www.milan urbanfoodpolicypact.org/wp-content/uploads/ 2017/10/MPA-winners-2017.pdf

Moragues-Faus, A., \& Morgan, K. (2015). Reframing the foodscape: The emergent world of urban food policy. Environment and Planning A: Economy and Space, 47(7), 1558-1573.

Moragues-Faus, A., Morgan, K., Moschitz, H., Neimane, I., Nilsson, H., Pinto, M., ... Halliday, J. (2013). Urban food strategies: The rough guide to sustainable food systems (GA No. 265287). Brussels: Foodlinks. Retrieved from http://www.foodlinkscommunity.net/ fileadmin/documents_organicresearch/foodlinks/ publications/Urban_food_strategies.pdf
Raad voor het Openbaar Bestuur. (2012). Loslaten in vertrouwen: Naar een nieuwe verhouding tussen overheid, markt en samenleving [Letting go in confidence: Towards a new relationship between government, market and society]. The Hague: Raad voor het Openbaar Bestuur.

Renting, H., Schermer, M., \& Rossi, A. (2012). Building food democracy: Exploring civic food networks and newly emerging forms of food citizenship. International Journal of Sociology of Agriculture and Food, 19(3), 289-307.

Roberts, N. (2004). Public deliberation in an age of direct citizen participation. The American Review of Public Administration, 34(4), 315-353. https://doi.org/ $10.1177 / 0275074004269288$

Schön, D. A., \& Rein, M. (1994). Frame reflection: Toward a resolution of intractable policy controversies. New York, NY: Basic Books.

Snow, D. A. (2004). Framing processes, ideology, and discursive fields. In D. A. Snow, S. A. Soule, \& H. Kriesi (Eds.), The Blackwell companion to social movements (pp. 380-412). Malden, MA: Blackwell.

Snow, D. A., \& Benford, R. D. (1988). Ideology, frame resonance and participant mobilization. In B. Klandermans, H. Kriesi, \& S. Tarrow (Eds.), From structure to action: International social movement research 1 (pp. 197-217). London: JAI Press.

van Hulst, M. J. (2008). Quite an experience: Using ethnography to study local governance. Critical Policy Studies, 2(2), 143-159.

Viljoen, A., \& Wiskerke, J. S. C. (2012). Sustainable food planning: Evolving theory and practice. Wageningen: Wageningen Academic Publishers.

\section{About the Authors}
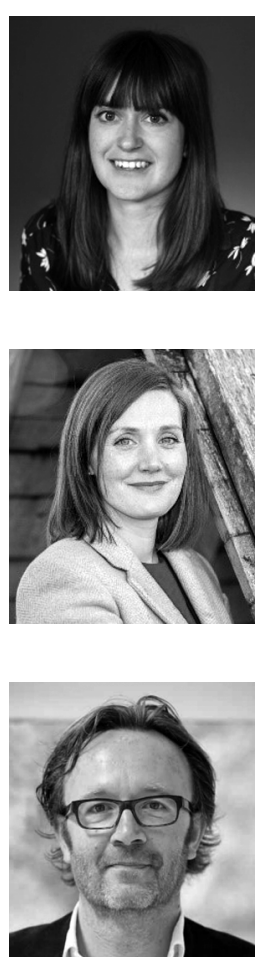

Johannes S. C. Wiskerke (PhD) is Professor and Chair of Rural Sociology at Wageningen University. His research activities focus on: a) the dynamics and socio-economic impacts of multifunctional agriculture; b) alternative food networks and their impact on rural and regional development; and c) urban food provisioning and city region food policies. Currently he is involved in two research projects: A Horizon 2020 project exploring urban-rural relations and synergies (ROBUST) and a project entitled 'Urbanising in Place'. 